\title{
ELECTRICAL INSTRUMENTS IN 19TH CENTURY FRANCE, BETWEEN MAKERS AND USERS
}

\author{
CHRISTINE BLONDEL
}

CRHST (CNRS/Cité des Sciences et de l'Industrie) 75930 Paris, Cedex 19, France

\begin{abstract}
Having quickly described new historiographical approaches to scientific instruments, this paper explores some characteristics of the evolution of the relationship between scientific instrument makers and French physicists in the 19th century. Artisans without a scientific culture at the dawn of the century, a certain number of instrument makers were integrated into the scientific community by its end, sharing their practices and their values. These builders served as mediators between different physicists, between physicists and members of other disciplines like physiology and, finally, between savants and the world of technology (telegraphy and then industrial electricity). Symmetrically, a significant number of French physicists left mathematical physics for a physics based on instruments and their development. The emergence, extension, and eventual disappearance of the different contexts of use of an instrument (amateurs, public performances, teaching, research, medicine, telegraphy, industry, etc) illustrate both the boundary crossings between these different domains and the major role that use played in successive reconfigurations of instruments.
\end{abstract}

Résumé: Après un aperçu sur le renouveau historiographique concernant l'étude de l'instrumentation scientifique, cet article propose quelques caractéristiques de l'évolution des rapports entre constructeurs d'instruments scientifiques et physiciens français au cours du $19 \mathrm{e}$ siècle. Artisans sans culture scientifique au début du siècle, un certain nombre de constructeurs s'intègrent à la communauté scientifique à la fin du siècle, partageant ses pratiques et son système de valeurs. Ces constructeurs deviennent des médiateurs entre les différents physiciens, entre les physiciens et les membres d'autres disciplines comme la physiologie et enfin entre les savants et le monde technique (télégraphie puis électricité industrielle). Symétriquement une partie importante des physiciens français délaissent la physique mathématique au profit d'une physique tournée vers l'instrument et sa mise au point. L'apparition, le développment et l'éventuelle disparition des différents contextes d'usage d'un instrument (amateurs, démonstrations publiques, enseignement, recherche, médecine, télégraphie, industrie ...) montrent à la fois les traversées des frontières entre ces différents domaines et le rôle majeur des usages dans les reconfigurations successives que subissent les instruments.

After having been neglected for many years, the history of scientific instruments is now one of the most lively areas of research in the history of contemporary science and so, indirectly, of technology. On the one hand historians have taken up, from a somewhat different angle and usually for more recent periods, Derek de Solla Price's arguments on the importance of instrumentation and experimentation in the ongoing history of the sciences, and his stress on the diversity of roles which they play.' In addition radical criticisms have been levelled at historians and philosophers who, like Koyré or Bachelard, themselves reacting 
against an earlier period noted for its positivism and empiricism, have seen instruments as objects determined by theories whose main purpose was to enable one to confirm the latter.' As Jim Bennett has stressed, we are heirs of the inversion of the relative weights accorded to practice and to theory, and we easily fall into the trap of forgetting that this hierarchy of values was constructed through an historical process.' In other words, having now moved beyond the simplistic picture, consecrated by Whewell in the middle of the 19th Century, of the instrument as a provider of data needed for the verification or the testing of hypotheses, historians of science interested in the technological and other infrastructure of scientific practice have begun to explore a large variety of questions: the context or space in which instruments are used (public places or private places, the individual laboratory or the collective teaching or industrial laboratory... ), their social functions, the transfer of knowhow, tacit knowledges, the difficulty of replicating experiments, the growing importance of recording techniques, standardisation and the transformation of an instrument into a black box, the importance attributed to precision, etc.

The history of scientific instruments themselves, often focussed on their technical aspects, and generally on a collection or a specific instrument (taxon omy, attribution, functioning, morphology,... $)^{4}$ has simultaneously opened out in new directions, like the performances of instruments, the constitution of collections, the establishment of a professional group of instrument-makers and their relations with scientists. As a result, instrument-makers, until recently reduced to the suppliers of apparatus, are thought to have been important actors in both scientific development and the industrial revolution.' In 1984, at the 4th Inter-national Conference on Scientific Instruments, dedicated to instruments in the 19th Century, Robert Anderson could justly say "This can be brief! (...) As yet, we know rather little about instrumentation and its background in the 19th Century".' Things have changed. As regards physics instruments of the 18th and 19th centuries to the work of G. Turner, A. Middleton, J. Payen, W. Hackmann, P. Brenni, J. Bennett, J. Millburn, A. Turner, and A. McConnell have been added studies by S. Schaffer, T. Lenoir, N. Wise, D. Gooding, M. Dörries, O. Sibum, G. Gooday, I. Morus, M. Williams P. de Clercq, A. Brachner, B. Gee, etc. Collective works and numerous catalogues of collections have been published, notably in Italy.' A journal has been established and doctorate theses which give considerable weight to the topic of instrumentation have recently been defended.'

Industrial history, for its part, can help us see instruments from another angle, freed from the supposed subordination of technology to science, and sensitive to the importance of instrumentation as an independent branch of industry. Even if relatively small in terms of number of employees, size of output, and investments made, this sector nevertheless had a quite specific role. It was a leading-edge industry by virtue of its situation in the process of innovation and a strong export-oriented tradition.' To these we must add the increasing role of instrumentation in the science-based industries in the 19th Century and, more generally, in the control of industrial processes. If the uses of instruments in non-academic circles in the 17th and 18th centuries - essentially in the service of navigation and geodesy - have been well studied by historians, we still know very 
little about the scale of the phenomenon in the subsequent century, where we find instruments penetrating, along with teaching and research, the worlds of industry, of medicine, and even of administration. As D.J. Warner has stressed, physicists have continued to take for granted the traditional claim as expressed by Maxwell that "The aim of Physical Science is to observe and interpret natural phenomena", even if an ever-growing part of their work on instruments was linked to other scientific disciplines or to other social demands. $^{\circ}$

The term instrument will be used in this paper in the broad meaning which it had throughout the 19th Century. In France the label 'precision instruments', which one finds in commercial yearbooks from the middle of the century onwards, gradually imposed itself, particularly via the classification of the Universal Exhibitions. At the dawn of the 20th Century Maurice d'Ocagne, a professor at the Ecole des Ponts et Chaussées, defined them as instruments "intended for measurement, observation or calculation". 11 Yet let us not forget that many 'instruments' in the 19th Century sense of the term were not used to 'observe' (in the sense of observation with a microscope or a telescope) or to produce quantitative data. In the case of electricity, we need only mention Barlow's wheel which illustrated the influence of a magnet on an electric current, De la Rive's egg which simulated the aurora borealis, models of motors, discharge tubes, etc. ${ }^{12}$ One possible framework of analysis would be the range of apparatus sold by instrument makers during the period under review, a range revealed through the commercial catalogues. ${ }^{13}$ These often covered measuring apparatus, batteries, models of motors, telegraphic apparatus, and so on. 14 Indeed it was precisely during the 19th Century that the term instrument gained its specificity and, in particular, was distinguished from machine. Lavoisier's calorimeter was initially presented as a "machine', and Coulomb's balance was described as "an ingenious machine", a phrase which also referred to its origins in the knowledge of engineers. By contrast, by the end of the 19th Century the term 'machine' seems to have been restricted to instruments intended for production - of energy, of cold, of a vacuum, of electricity... What is more, in the course of the century, the instrument was more and more rarely used on its own, and was transformed from being a self-contained individual instrument into being an apparatus. ${ }^{15} \mathrm{It}$ was built into assemblies, into wider complexes. The changes in the meaning of the term are symptomatic of changes in scientific practice itself.

Norton Wise has described the potential functions of instruments or technical objects as "mediating machines" or mediating actors between different scientific disciplines or between scientific domains and sectors of the economy or of culture. 16 Thus during the second half of the 18th century in France the balance - and more generally the techniques of equilibrating two entities - took shape, and facilitated the transfer of the central notion of equilibrium from one scientific field to another. The steam engine, the mediator between the world of industry and that of physicists in the 19th century, led, in Thomson's work, to a science of mechanics based on the concepts of energy and output rather than that of force. The technical object, or instrument, allowed for the circulation of a way of understanding the world between different subcultures. To this possibility, which is situated here basically in the field of the history of ideas, we can add another, 
more concrete, and which concerns the nature of many instruments as open finalities, nonpredetermined, flexible, characteristics which allow certain instruments to follow very different trajectories. For G. Turner "instruments and manipulative skills (...) are in themselves neutral"; an astrolabe can be just as useful to estimate the hour from the sun, to find the latitude at sea from a stellar reference point, or to collect the data needed to build a horoscope. ${ }^{17}$ Of course instruments in the modern period more often than not underwent changes in their configuration, their design and their materials, their techniques of use, their criteria for qualification, and so on, depending on their use in different contexts. Nevertheless, some of them bear witness to an enormous diversity of functions or statuses. Put differently, we can say that the nature of an instrument is far from being always defined from its inception, and that it is partly determined by its uses. The induction coil, one of the most widespread electrical apparatuses in the 19th century, illustrates this point nicely. Whether one defines it by its composition (a secondary coil around a primary coil connected to a battery and an intermittent switch), or by its physical principles (to produce rapidly changing induced currents), one can justify the unchanging character of its name and its identity. By contrast, if one compares the coil for individual therapautic use, kept in a cigar box, with an enormous apparatus destined to produce some hundreds of thousands of volts for wireless telegraphy, one is obviously dealing with quite different objects. The evolution of the instrument goes along with the diversification of its uses which include the experimental study of induced currents, electrotherapy, scientific displays, X-ray radiography, wireless telegraphy, and so on (Fig. I (a-e)). It is indicative of the multiple changes, and of the delicate and permanently ongoing reconfiguration of the instrument for new purposes.

The considerable increase in the use, and so in the manufacture, of scientific instruments in the 19th century was connected to the extention and diversification of their territory, and were a consequence of the drastic changes brought about by the organisation of science, teaching, public health and industrialization. The relative stability of the market for instruments in the 18th century was followed by a huge variety of new demands. Even if, for physicists, electricity was a subsection of their discipline with its well-defined body of knowledge, and described in many texts with similar content, the objects which enabled them to produce, observe and measure the effects they studied crossed the boundaries separating academic physics, physiology, medecine, telegraphy and industrial electricity. This mobility did not affect all parts of physics in the same way. Thus magnetic instruments (essentially different compasses and magnetometers) barely moved beyond the borders of navigation, geodesy and university science, even if measuring procedures and manufacturing processes were radically transformed. 18 By contrast, electrical instruments were equally at home in a university laboratory, a cabinet in a lycée, a hospital or a doctor's consulting room, a private home, a public show, a telegraphy station, a meteorological centre, an observatory, a boat, a construction workshop, an electric power station, a control laboratory. These crossings could turn instruments into the privileged mediators between different communities. They were further facilitated by the fact that in the context of the second half of the century, contact with science was above all effected via the objects 
LES EXPERIENCES PUBLIQUES D'ELECTRICITE'

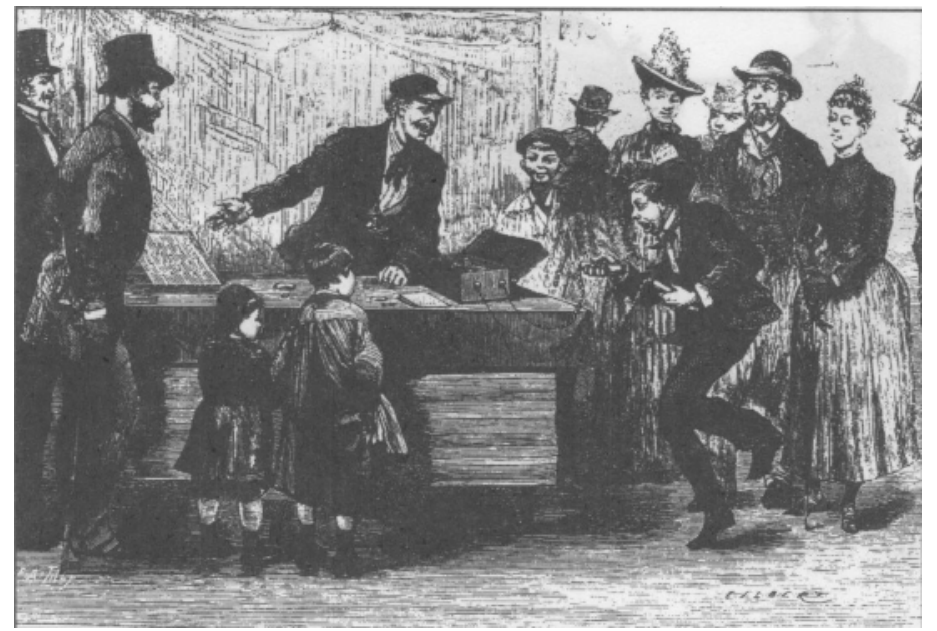

Figure 1(a) The itinerant electrician at the La Villette fairground (La Nature, 1889).

Figure 1(b) The reproduction of the "aurora borealis light with an electric discharge in the De la Rive egg (a glass globe filled with rarefied air). 


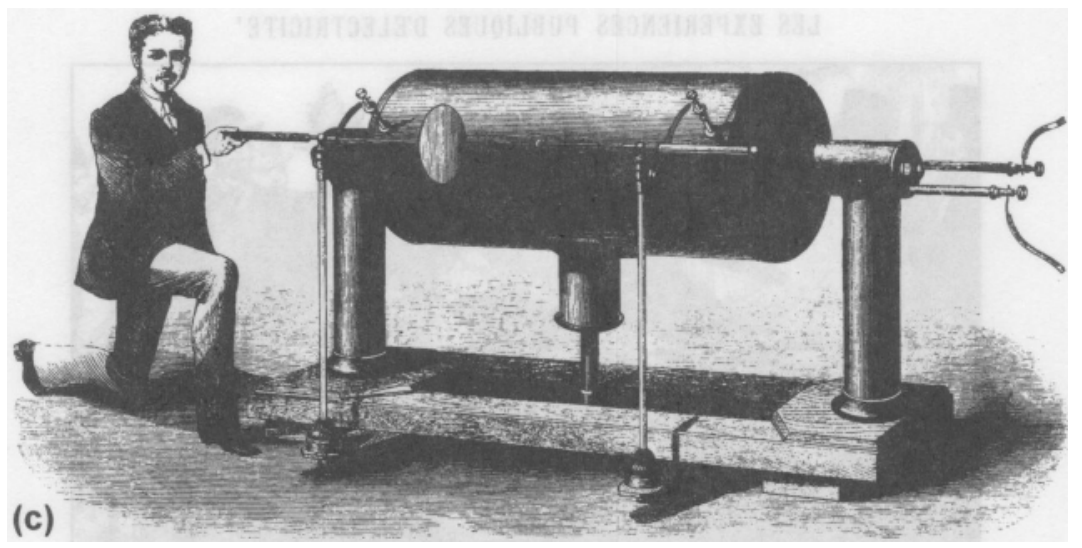

Figure 1(c) A big Ruhmkorff coil for public spectacles, producing sparks about $60 \mathrm{~cm}$ long.
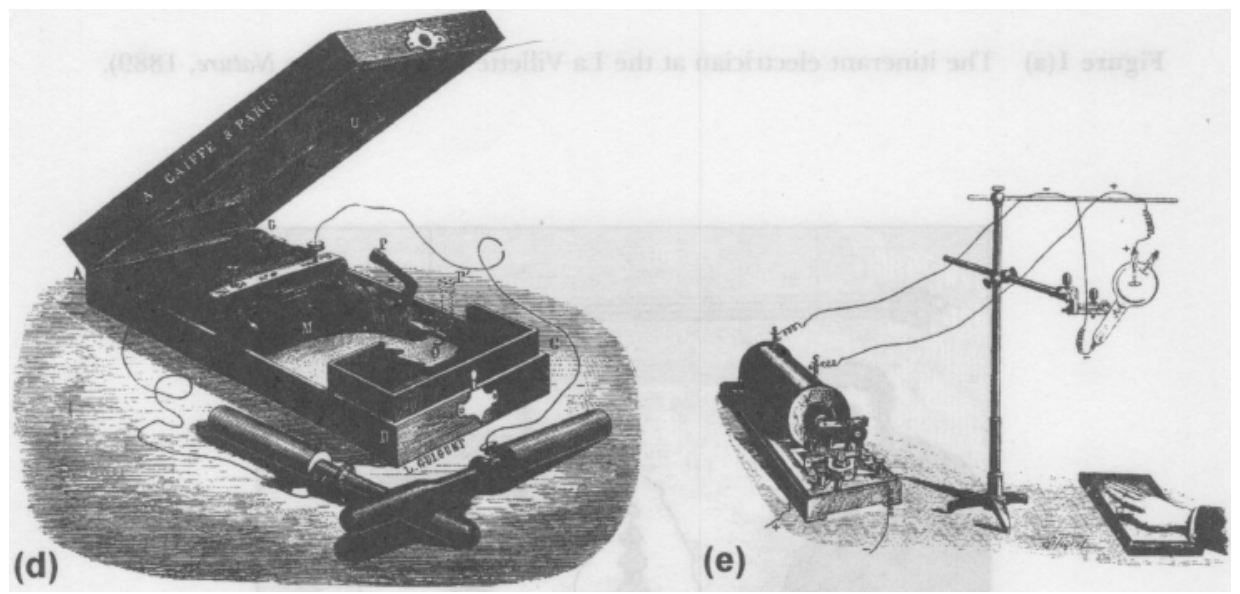

Figure 1(d) A small portable induction coil used for medical electricity. The two cylinders are put on different places on the body (c. 1870).

Figure 1(e) The induction coil as a supplier of high voltage to a vacuum tube producing X-rays for radiography (c. 1898).

of science, be that through picture, public displays, or personal use. Hence the importance of "leçons de choses" (lessons of things) in French primary school.

As the editors of Invisible Connections have suggested, a good methodological rule for studying the science-industry interface could be "to follow the instru ment", (to which we would add, and the associated practices), and so to cross the boundaries. ${ }^{19}$ Thus if we now travel along with some of the main electrical objects during their peregrinations and mutations in the course of the 19th century, we can hope thereby, and notwithstanding the risks inherent in any study of the 
longue durée, to grasp how not only scientists, but also technicians or doctors, benefitted from, reworked and reinvested in or, on the contrary, rejected the products of the labours of their predecessors: in short how new configurations were put in place.

\section{INSTRUMENT MAKERS: FROM ARTISANS TO THE SOCIÉTÉ FRANÇAISE DE PHYSIQUE 20}

Makers of physics instruments emerged as a professional specialism in France in the second half of the 18th century at the core of those who were making mathematical and optical instruments for the sciences, especially astronomy, but also — and above all — for navigation and surveying. As artisans, they were subject to the regulations of the guilds (smelters, mirrormakers, carpenters, enamellers...) and came up against difficulties when they wanted to use techniques mastered by different skill-groups. It was the savants who, at the dawn of the Revolution, took the initiative to put a stop to this constraint on the work of the makers. At the instigation of the Académie des Sciences, and in the name of the general interest, an independent guild of engineers dedicated to the construction of scientific instruments was set up, though it only survived a few years. ${ }^{21}$ The Académie des Sciences' Committee, which fixed the modalities for recruitment into this group, laid down that candidates had to have an elementary knowledge of geometry, physics and mechanics. This requirement was however, never applied in practice. Most instrument makers, including those who comprised the elite of the profession, like Nicolas Fortin (the recognized instrument maker for Lavoisier and the Académie des Sciences), or Etienne Lenoir (supplier for the Observatory as well as the geodesic instruments needed for the triangulation of French territory), both of whom were among the first to have the certificate of engineer of scientific instruments, could barely read or write. ${ }^{22}$ The case of Abbot Nollet and of Sigaud de la Fond, who grew steadily more prestigious by constructing instruments and writing scientific books, and by giving public and private lessons, might suggest an overlapping between the communities of savants and instruments makers. But they were exceptions. Indeed they only built their instruments in small numbers, and when asked to do so. Those who made public demonstrations and who, alongside their classes-performances sold the most common instruments, bought what they needed from licensed artisan builders.

From the early 19th century onwards one no longer finds the showcases of rich amateurs in France. The collections of instruments seized in the Revolution were not rebuilt by the aristocracy or the bourgeoisie during the Restoration. Of course most instrument makers continued to sell objects regarded to be scientific curiosities and, from the mid-century onwards, they enlarged the scope of their production to include other domains like photography and telegraphy. The variety of the output and the porosity of the boundaries between applications was reflected by the catalogues, where objects were still often classified according to their kind and with their different uses all mixed up together. So, for example, the category of Leyden jars could include a model to accumulate very large 
quantities of electricity and intended for research, a jar to be used to demonstrate for teaching purposes that electric charges were to be found on the surface of the glass and not on the metallic frame, a jar with its frame decorated with diamonds which provided "wonderful luminous effects in the dark", a jar to be used to heal paralysis, another to treat the deaf. ${ }^{23}$ Indeed many apparatuses could be used in very differents contexts.

Teaching and research did nevertheless now represent a major fraction of the instrument market. 24 The Revolution had already provided numerous occasions for collaboration between savants and instruments makers: the work of the Commission for Weights and Measures and the setting up of the metric system, the installation of Chappe's optical telegraph network, the inventories of the collections appropriated by the Temporary Commission for the Arts, the meetings of the Bureau for Consultations on Arts and Crafts . The creation of secondary and higher institutions of learning (Central schools and then lycées, university, Conservatoire des arts et métiers, Ecole polytechnique, and so on) went along with the disappearance of the mixed profile of public demonstrator/instrument maker which was transformed into that of a professor. Henceforth education became a permanent place of meeting and transition between the milieu of professors and that of artisanal instrument makers. The posts of preparateurs, of curators of collections, of the head of the workshop in a technical school were created. A large number of those who filled these positions, considered to be junior, later became professors themselves in somewhat less prestigious institutions. Some instrument makers, however, moved into the new professions which were to be found at the heart of their market. Thus among the more important of those directly concerned with electricity, Gambey and Chevalier were heads of workshops in the Ecoles des arts et métiers for rather a long period of time, Ruhmkorff was the assistant of a Parisian physics professor, J.G. Bourbouze was preparateur at the Sorbonne, G. Séguy was preparateur at the School of Pharmacy, J.T. Silbermann and A. Gaiffe were preparateurs at the Conservatoire des arts et métiers. Their workshops were situated in the centre of Paris, not far from the Sorbonne, the Collège de France, and the major engineering and Institute schools, from where the instrument makers were at the disposal of the professors, henceforth their most important clients.

The relationship that was built up was, it should be stressed, far more complex than simply that of client and supplier. For many years experimental research had been shaped by the manipulation of techniques which were available. For its part, the fabrication of precision became increasingly an offshoot of scientific knowledges. Savants and instrument makers had to negotiate to arrive at a compromise between the desirable and the achievable. In this close association which often led to a genuine experimental collaboration, the instrument maker was no longer the 'invisible technician' of the start of the 18th century as described by S. Shapin. ${ }^{25}$ A dozen exhibitions of French industry held from 1798 to 1844 consecrated their place within industry. Instrument makers also conquered some positions in scientific and technical institutions. Two posts were reserved for an artiste and an artisteadjoint alongside a dozen scientists in the Bureau for longitude from its creation in 1795.26 Some became members of the Committees 
for the Society for Encouragement of National Industry and the Bureau for Consultation on Arts and Manufactures.

All the same the role of the instrument maker was clearly bounded. During the first decades of the century those like the Dumotiez brothers, who supplied the Sorbonne and the Ecole polytechnique, or the Pixii father and son (the latter built the first magnetoelectric machine in 1832), or Gambey who developed the most sensitive instruments for the Paris Observatory, or again Froment who worked in particular with Arago, did not publish. So we find Arago at Gambey's grave, making a public appeal, in his capacity as secretary of the Académie des Sciences, to the memory of a dividing engine which Gambey had never described in writing. The makers only left a few instruments behind them, the inventories of their collections after their deaths, a few rare catalogues. ${ }^{27}$ Their names were only rarely mentioned by the physicists. The boundary between intellectual and manual labour was still clearly defined.

We notice a reassessment of the significance of the instrument maker beginning around 1840-1850. Eulogies on their many qualities, and the demand that they be legally recognized were publicly made both at the Academy by Arago and by Napoleon III who visited their workshops on several occasions. ${ }^{28}$ The role of the instruments was systematically mentioned with increasing frequency by the savants in their scientific communications. In the close and more or less durable relations between a savant and his instrument maker of the moment - Foucault and Froment, Fizeau and Breguet, Arago and Gambey, Jamin and Dubosq, and so on (only to mention those concerned by electricity and magnetism) - the role of the latter, crucial for the refinement of experiments, was explicitly recognized. This partnership was to be evoked with some nostalgia at the end of the century by Alfred Cornu, professor at the Ecole polytechnique, who felt that it was now disappearing. 29

Education by apprenticeship ensured the command of traditional technical knowledges. One thus finds continuous chains of master and apprentice stretch ing over more than a century: Lenoir (1744-1832) trained Gambey (1787-1847), who trained Froment (18151865) who, in turn, trained Ducretet (1844-1915). At the same time, the increasingly direct and personal involvement of the instrument makers in experimental work led to their having an ever better appreciation of its scientific content. To improve their knowledge even more, they attended the courses (which were public and non-paying) of their 'clients' at the Conservatoire, the Sorbonne or the Collège de France. In the second half of the century instrument makers like Adolphe Gaiffe, J.G. Bourbouze, Louis and Antoine Breguet, Eugène Ducretet became both physicists and writers. In their activity as entrepreneurs, many of them paid more attention to research on instruments and to the study of technical innovations than to the management of their business. Ruhmkorff, for example, worked on the development of the coil that bears his name, but apparently did not produce a catalogue of his instruments, and very little capital remained after his death even though he had exported his products throughout Europe for several decades. Breguet studied the theory of Grammes' machine, Ducretet carried out the first experiments with wireless telegraphy, Carpentier developed the first camera for the Lumière 
brothers. They carried out experiments out of personal interest, and published notes in the Comptes rendus de l'Académie des sciences and in various scientific journals, contributions which went well beyond a simple description of their instruments. 30 Some published genuine treatises. Some even penetrated the world of education, like Bourbouze who opened a laboratory for scientific teaching. ${ }^{31}$ They subjected themselves to the credit system and values cherished by savants: production and diffusion of knowledge, modesty, disinterestedness. They sent their sons to the Grandes Ecoles at the end of the century, and these were effectively integrated into the scientific community, holding many positions in the main French societies scientific and technical: Société française de physique, Société française de photographie, Société internationale des électriciens, Société d'encouragement pour l'industrie nationale.

The meetings of the Société française de physique, established in 1873, are particularly revelatory of the status then acquired by the instrument makers. Having as aim to demonstrate before its members "the most interesting and novel experiments", these fortnightly meetings brought together professors, engineers, instrument makers, electricians, people who were simply curious, in a room which, as the first president Fizeau enthusiastically pointed out, was close both to educational institutions and to the workshops of the main instrument makers. ${ }^{32}$ In 1875 , during his annual speech, the new president Pierre-Auguste Bertin, maître de conférence at the Ecole Normale stressed the pleasure to be had from "the experiments which ensured a full attendance at all our meetings". 33 In fact, theoretical communications were largely in the minority until the 1890s. And when Jules Jamin, professor at the Sorbonne and at the Ecole polytechnique expressed his satisfaction at the number of instrument makers who were members of the Société, affirming that "here experiment and practice are as honorable as theory", he was not simply resorting to rhetoric. 34

Two instrument makers served on the Société's Council. And during meetings the presentation of instruments and the demonstration of experiments by the instruments makers or by professors from the most prestigious scientific institu tions followed on one another without any evident hierarchy. We have moved from an individual and hierarchized relation between professor and maker to a free joint association. Throughout the latter half of the 19th century international Exhibitions, which demanded the three-dimensional presentation of science, projected instruments - and so those who made them - to the forefront. This was also a regular opportunity to insert the latter in a genealogy which linked them with the great names of science. Indeed when history of physics was presented on these occasions it was mediated through a succession of historical instruments. Instrument makers, it must be said, did not only benefit symbolically from these Exhibitions - they. were paid important sums of money under the Second Empire, notably through the intermediary of the Conservatoire des arts et métiers. That said, exhibitions, even if they facilitated the diffusion of information on innovations, were too brief and irregular, and took place in a context that was too superficial, for there to be genuine exchanges between savants and technicians. It was the Société française de physique which provided the regular meeting place necessary for meaningful discussions. 
In the decades 1870-1880 the creation of journals dedicated to electricity, La lumière électrique, L'électricité, L'électricien and others, opened the way for several instrument makers to be on the editorial boards of journals. ${ }^{35}$ Even a journal of general interest like La Revue scientifique in 1880 invited the builder of electrical appara tusses, Antoine Breguet, baptized 'young savant' by its previous director, to edit the journal along with the physiologist Charles Richet. ${ }^{36}$ At the end of the century the lionization of some instrument makers, like A. Bréguet or J. Carpentier, polytechnicians both, the latter elected to the Académie des sciences, bears witness to the profound change in status of French instrument makers.

This high esteem was twinned with the instauration of what the worker-mechanic, member of the union of precision instrument workers and future anarchist, Paul Delesalle, would call the "golden age" of French instrument making. ${ }^{37}$ The setting up of the network of electrical telegraphy contributed - in the field of electricity - to the increase in influence of French instrumentation thanks to public orders. The birth of industrial electricity, based on private industry, was not as advantageous. With the inception of electric lighting, followed by the introduction of electric motors in industry and transport, instruments passed from artisanal to industrial scale. They were increasingly standardized and their catalogues became increasingly impersonal. The workshop, linked closely to a constellation of individual subcontractors, was replaced by the factory and, from the last years of the century onwards, the individual owner was replaced by the public company. Commercial strategies and investments were essential for survival. It was at this time that French leadership in instrument making began to decline. This decline, which was part of a general crisis in the French economy, was attributed by its contemporaries to the poverty of resources in the university laboratories, to the absence of national laboratories as in Germany and, in general, to lack a of state support, the inadequacy of investments, a preference for 'high precision' rather than for mass production, the withdrawal of scientific directives in the construction of common instruments, the lesser use of mechanization and, finally, to legislation on patenting which was less advantageous. 38 Jacques Payen saw what he called the continuation of an "artistic mentality" among the instrument makers throughout the century. ${ }^{39}$ Perhaps more important than the artistic mentality were the close ties with the community of savants.

In any event, this decline is evident from a study of the collections of instruments in European teaching and research establishments, where French instruments are replaced by those coming from Germany and then Britain or the United States at the dawn of the 20th Century. 40

\section{INSTRUMENTS MAKERS AND THEIR INSTRUMENTS: MEDIATORS BETWEEN DIVERSE COMMUNITIES}

Instrument makers served as bridges between different scientific and technical communities. Even within the community of physicists, before the establish ment of the Société française de physique in 1873 , they played a role which, albeit 
somewhat obscure - due to the paucity of written sources - , was surely not without importance. In effect each physicist worked in his own laboratory, and it was apparently unusual for him to go and work in that of another professor. ${ }^{41}$ The place where physicists met, be that the meetings of the Académie des sciences or those of the Société philomatique, were non-specialized spaces where talks on mathematics, physics, chemistry, and the natural sciences followed one after the other. The rapid presentations of instruments made there certainly did not permit one really to get to know them. On the other hand, each physicist was in direct contact with one or more instrument makers whom he went to see regularly in his workshop. 42 Only there could he define precisely what he wanted and be made aware of the latest technical advances, and even sometimes carry out tests or make measurements. Some letters from the end of the century bear witness to these exchanges which were of course essentially oral. 43 The instrument maker who hosted different Parisian physicists in his workshop could circulate information between them. Professor and instrument maker also met each other at the Société d'encouragement pour l'industrie nationale and the Bureau for Consultation on Arts and Manufactures of the Minister of Commerce and Industry. And even though it is difficult to be certain - in the absence of historical studies - of the role which these institutions had as sources for the stimulation and evaluation of innovation, they were in any event places in which instrument makers and savants had regular discussion with each other. Physicists were often asked on such occasions to give reports on technical objects and on instruments.

Sometimes an intermediary could come between the savant and the instrument maker: the preparer (préparateur). Drawn from a population that was often young and about which we know very little, the preparers had a relationship to the instrument makers' workshop which was at least as close as that of the professor since they took care of the equipment. They frequently changed from one scientific establishment or laboratory to another, from the Ecole de pharmacie or de médecine to the Sorbonne or the Ecole polytechnique. Thus Bourbouze was a preparer at the Ecole de pharmacie and at the Sorbonne, F.P. Le Roux was preparer at the Conservatoire and assistant at the Ecole polytechnique, A. Peignot was preparer at the Collège de France and at the Museum, J.T. Silbermann was preparer at the Sorbonne and the Collège de France while his brother was curator of the physics collections at the Conservatoire. These preparers circulated information, know-how, and the tricks of the trade.

During the second half of the century the builders of electrical and telegraphic apparatus also worked with another category of scientist: the physiologists. Indeed at this time batteries, galvanometers, induction coils and other items of electrical equipment were becoming part of the physiologist's stock in trade. Some of these apparatus were even deliberately developed for physiological applications. For example the galvanometer built by the Italian physicist Nobili, which was a standard instrument between 1830 and 1860 , like that constructed by the Frenchmen Marcel Deprez and d'Arsonval which was common in the $1880 \mathrm{~s}$, were specifically conceived to measure the weak, variable currents associated with muscular contractions. The physiologist-doctor Charles Richet met 
Antoine Breguet, with whom he would edit the Revue Scientifique, to perfect the experiments on the stimulation of a lobster's claws by an electrical current. Techniques like those of intermittent current switches were first developed for the therapeutic uses of the induction coil, and only later for telegraphy or industrial electricity. Sometimes instruments passed directly from one domain to another. The high frequency generator build by Ducretet for d'Arsonval's medical research was taken up by colonel Ferrié to equip his wireless station on the Eiffel tower at the very start of the 20th century. Instrument makers and their instruments served as the lynchpins within and between different research communities.

The maker's workshop was also a meeting place between physicists and the technical world. Many builders, like Louis Breguet and Gustave Froment, worked for academics as well as for railway or telegraphy administrations and for industry. Professors studied along with them electromagnetic brakes for trains, various kinds of alarms and triggers, detonators, batteries for telegraphs, electrical synchronisation systems for public clocks, and so on. It was in Froment's workshop, where he was artisan, that Zenobe Gramme met the Italian physicist Pacinotti who had come to Paris to buy instruments and was trying to develop his electromotor. ${ }^{44}$ It was with a microphone and a Bell telephone built by Breguet that Arsène d'Arsonval, Claude Bernards' préparateur at the Collège de France, demonstrated certain electrical properties of muscles. Continuing re- search on the microphone with Paul Bert, professor of physiology at the Sorbonne, d'Arsonval developed a new carbon microphone, with magnetic regulation, which would be adopted by the telegraph administration. ${ }^{45}$ Borrowed from the technology of telegraphy to be used as a tool in the service of physiology, then perfected in physiology laboratories, the apparatus returned to the world of technology.

Finally, at the heart of that same technological world the instrument makers played a very special role thanks to their ongoing proximity to technical innovation. Innovations made in order to build technically particularly demanding instruments, like those required by the scientists, could be taken up into other sectors of industry. These technical innovations were of many different kinds. They included, firstly, classical technologies, like the use and control of high-speed rotation, applied initially to light objects like mirrors and then to heavy objects like dynamo rings. 46 They were also applied to already existing and traditional technical objects: alongside Caselli's and Hughes' telegraphs, Froment developed an electric loom. 47 Nevertheless it was the new technologies which particularly attracted the French instrument makers. We have already mentioned Ducretet and the wireless telegraph, and Carpentier and the cinema, to which we can add Breguet and the Bell photophone ... They were among the first to use new metals like aluminium or nickel, to perfect new metallic amalgams and alloys, and to use electrometallurgy. ${ }^{48}$ Working along with different industrial branches (metallurgy, mechanics, the glass industry ...) builders could transfer innovation from one to the other. That is what happened with the builders of telegraphic apparatus who participated in the creation of an electric technology network which would play a predominant role in the start up of industrial electricity. 49

Thus we find that even if the large majority of the fifty or so French instrument makers recorded as working on electricity in the 19th century were satisfied 
to build everyday equipment for teaching or telegraphy, a dozen or so of them played a crucial role both as innovators and as crossroads of communication between different professional communities. Unlike what happened in Germany, however, where the collaboration between makers and physicists led to the setting up in 1865 of a journal entirely dedicated to instruments - the Repertorium für physikalische Technik - , and to its institutionalisation with the establishment of the Physikalische Technische Reichsanstalt in Berlin in 1887, in Paris the collaboration remained informal and was never supported by the state. ${ }^{50}$ In a time of economic liberalism it depended on individual initiative.

\section{THE INSTRUMENT AS BETWEEN THE `COMMERCIALIZATION OF LEISURE' AND THE 'COMMERCIALIZATION OF KNOWLEDGES'}

At the turn of the 19th century the 'commercialization of leisure', based on the exploitation of scientific phenomena for public spectacles and the admiration of 'curiosities' became considerably less prevalent among cultivated classes. ${ }^{51}$ Of course right up to the beginning of the 20th century - and increasingly for children - one sold electrical machines along with a whole gamut of accessories enabling one to perform different 'magical tricks: the electric canon, the small house through which lightening passed without damage, dancing puppets, electric chimes and mills, spark tubes, globes for the aurora borealis, and so on. ${ }^{52}$ At the end of the 18th century private persons were probably the most important market, in terms of volume, for scientific instruments and electricity was one of the most popular domains of science. The term 'electrician' was brought into use to qualify its adepts. However, with Coulomb's work, which was strongly supported by the Académie des sciences, and notably by Laplace and Haüy, amateurs were excluded from the new science of electricity. Laplacian physicists, in effect, introduced simultaneously two new tools which were indispensable for grasping this new science, tools which were virtually impossible to acquire by someone who had not had a scientific education: mathematical analysis and precision instrumentation. Along with this de facto exclusion of amateurs, the French physicist-mathematician refused any recourse to the spectacular, any experiment which could be seen as a magic trick. ${ }^{53}$ Henceforward the term 'electrician' referred to the travelling electrician who, until the end of the century, moved from fairs to village fêtes, performing some electrical experiments and above all offering some local excitement for a few pence. ${ }^{54}$ It was rather marginal to an instrument maker like Froment's usual activity to supply magicians like Robert Houdin and Robin with instruments for 'entertaining physics' (physique amusante). 55 For half a century French physics was ensconced in its equations, in its specialized journals and its laboratories - poorly equipped but closed. In 1853 the manual of the series of encyclopedias Roret, Le physicien-préparateur, the first work in French dedicated to the description of physics instruments since the Description et usage d'un cabinet de physique by Sigaud de la Fond, which appeared in 1775, complained of the 'closed doors' at the huge and superb instrument collections in French teaching establishments. 56 
During the Second Empire of industrialist, scientist, and populariser new kinds of scientific performances appeared within the framework of what Robert Fox has baptized the "commercialization of knowledge". 57 Directed at a bourgeois public desperately seeking novelty, scientific evenings blossomed - paid talks which were genuine shows but which also aimed to transmit a certain amount of scientific knowledge. Other, non-paying meetings were held for larger audiences, notably Parisian artisans. Whether fashionable or popular, due to private or public initiative, at the Sorbonne, at the Conservatoire, at private theatres, whether they were organized by Abbot Moigno, by the Association polytechnique, by the Association philotechnique, by the League for Teaching, or the Library of the Friends of Instruction, conferences sought to promote sciences as the source of all applications. 58 Spectacular experiments which mobilized a huge array of instruments perfectly manipulated were the main attraction for a public which could reach up to 2000 people. The speakers were often physicists like Jacques Babinet, professor at the prestigious College Louis le Grand, or Jules Jamin, professor at the Sorbonne and the Ecole polytechnique. Behind them the real directors were the preparers like Bourbouze who, as we have seen, combined the functions of preparer and instrument maker, and the constructor, like Ruhmkorff, who controlled his own coil. Ruhmkorff's coil and light phenomena (electric illumination, Geissler tubes, aurora borealis ...) stole the show. More and more impressive effects were sought for, and the coils became huge. With that at the Sorbonne Jamin demonstrated the volatilisation of metals by an electric arc projected on a screen, while with that at the Boulevard des Capucines, which was "powerful enough to kill an ox" the chemist Frémy demonstrated the decomposition of water.

Public conferences continued during the beginning of the Third Republic at the Sorbonne. In 1878 Eleuthère Mascart, professor at the Collège de France, in a talk on meteorology, used a "gigantic luminous pointer" to render visible the devia tion of an electrometer sensitive to the effects of atmospheric electricity in the court of the Sorbonne. $\mathrm{He}$ reproduced the lightening flashes in storms using an electrostatic Holtz machine and recreated the movements of electrically charged clouds using hydrogen-filled balloons. At the Conservatoire the audience was far more artisanal, and more practical applications were preferred. The appeal to experiments and to unusual effects were there in both cases, however. For the scientific evening of the 29 October 1864 one rolled $100 \mathrm{~km}$ of electric wire for the ever popular and even more powerful coil. ${ }^{59}$ In the 1880 s the conference-visits to the Conservatoire allowed more than 3000 Parisians to see in operation each Sunday electromagnetic machines, accumulators, electric lighting, and a whole series of experiments. Instrument makers and inventors, like Gaston Planté, the inventor of the lead accumulator, explained the principles of their instruments to those present. ${ }^{60}$ In contrast to these often very impressive demonstrations, the electric and luminous jewelry of the maker Gustave Trouvé, described at length in popular science journals, provided a less imposing image of electricity. It was thus a large public, from the popular to the managing classes, who became familiar with both electricity and its applications through experiments and the apparatus built for them.

Along with public demonstrations, books and popular science journals also drew attention to experiments and instruments rather than theories. During the 
latter half of the century a large variety of works described entertaining experiments to be done with "household or office" objects. Many others, and notably those dealing specifically with electricity, recognized implicity that it was more advisable to buy the key components for these experiments from a specialized instrument maker. Thus we find the builder A. Loiseau, the author of an illustrated pamphlet describing for a wide public the various experiments and applications of the Ruhmkorff coil - a pamphlet which was repeatedly republished between 1868 and the start of the 20th century - himself building and selling the coils and the apparatus which he described in his text. 61

\section{THE INSTRUMENT IN THE LECTURE THEATRE: WHERE THE 'CLASSICS' WERE TO BE SEEN}

The importance attached to experimentation and the instrument is also quite striking in teaching. It was situated in a practice of three-dimensional representation of material analogues for scientific and technical thought: terrestrial globes, wire figures representing the solutions of mathematical equations, geometrical and crystallographic models, demonstration steam engines, models of the parts of machines, scale, models of agricultural machinery, anatomical mouldings, and so on. ${ }^{62}$ Well before the dynamo allowed the use of electric motors in industry, models of electrical motors were being attached to mechanical models of mills, of presses, and of diverse mechanisms. These demonstration electric motors had an ambiguous status: to show the potential of electricity and to illustrate its properties, but also to integrate it into a world dominated by the mechanical. One finds an insistence on the description of instruments at all levels of teaching. Bertin reigned in physics at the Ecole normale supérieure from 1867 to 1884, and he placed an enormous stress on the description of instruments. ${ }^{63}$ Future professors were taught the techniques of instrument making by a specialist in the trade. In physics textbooks, and even more so in manuals prepared for the lycées, the description of instruments dominated. Whereas the German and above all British manuals tended to rely on schematic drawings, the French texts almost enabled one to build the described instrument, down to the last screw. ${ }^{64}$ Even if the "instrument bazar" of the lycées' collections, as Henri Bouasse, professor of physics at Toulouse university contemptuously described it, was rather technical, it hardly affected students. ${ }^{65}$ Practical work was introduced into French secondary education only in 1902 . Before that pupils and students had to be satisfied to watch, to note down the description, and to draw the instruments. In addition at the start of the 20th century, in the collections of lycées and universities, there were hardly any novelties. The physics cupboards in French lycées seemed, to quote Bouasse again, to be "antiquarian museums". In fact instruments for making electrical measurements which began to become common in industry from the 1880 s onwards were not to be found in university cabinets. On the other hand, one could find there all the historically important and pioneering instruments like Coulomb's balance or Ampère's table, on display though probably never used for a genuine experiment. In the teaching of the 
sciences, like that of the humanities, the 'classics' were apparently judged to be of greater educational value than the 'moderns'. The continuance of a certain French tradition was reflected in a style of electrical instruments going from Coulomb's balance (1785) right up to Branly's electrometer (1873), which involved long twisted wires and high glass tubes which made for instruments as sensitive as they were delicate to manipulate, and impossible to transport. British or German galvanometers or electrometers were generally more compact and were built into metallic, shock-resistant cases. (Figs. 2(a),(b)) These differences in

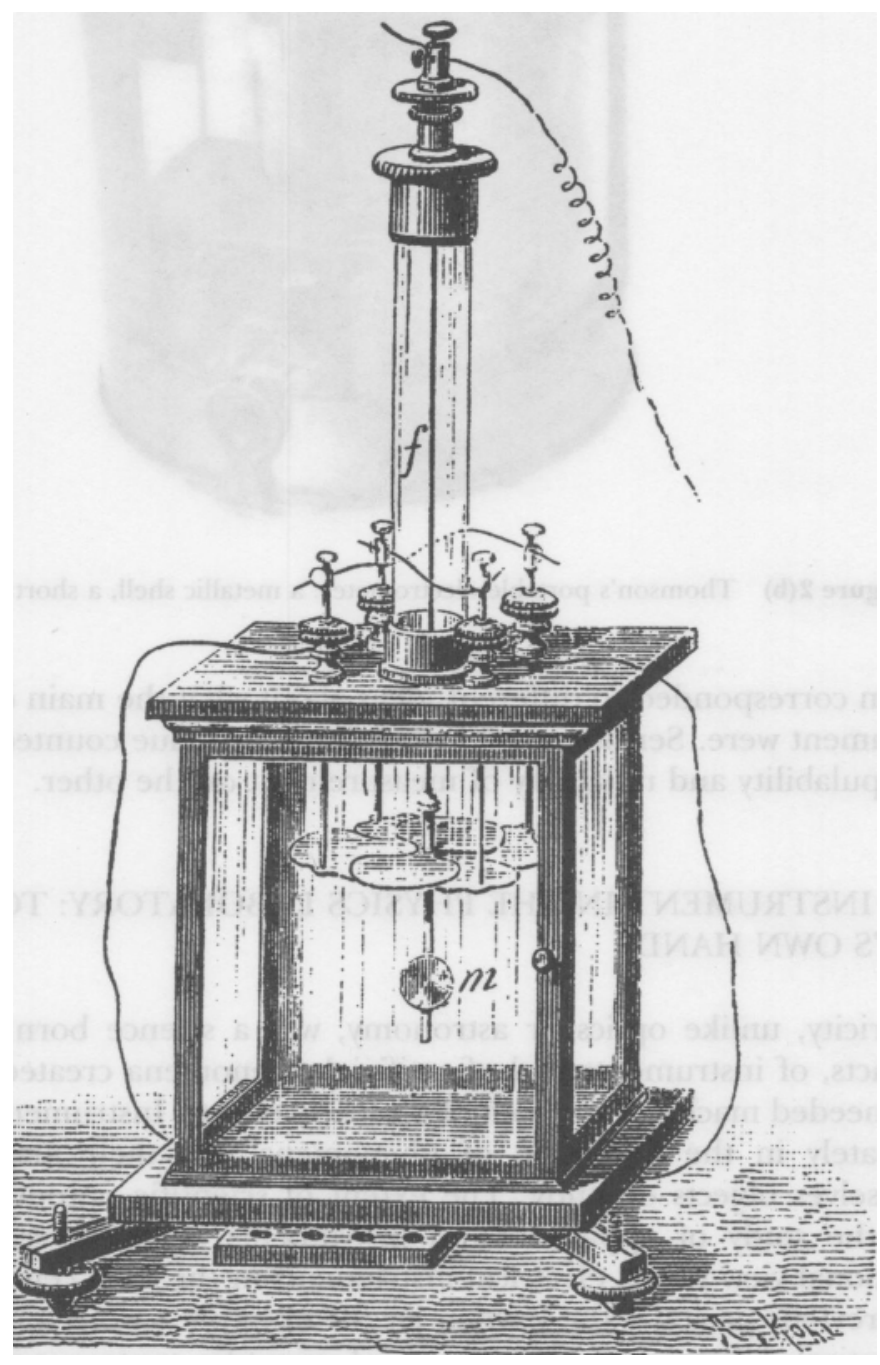

Figure 2 Two contemporary and very different versions of the same instrument, the Thomson electrometer used to measure electrical potential: (a) Branly's electrometer: a tube and a cage of glass, a long torsion wire (1872). 


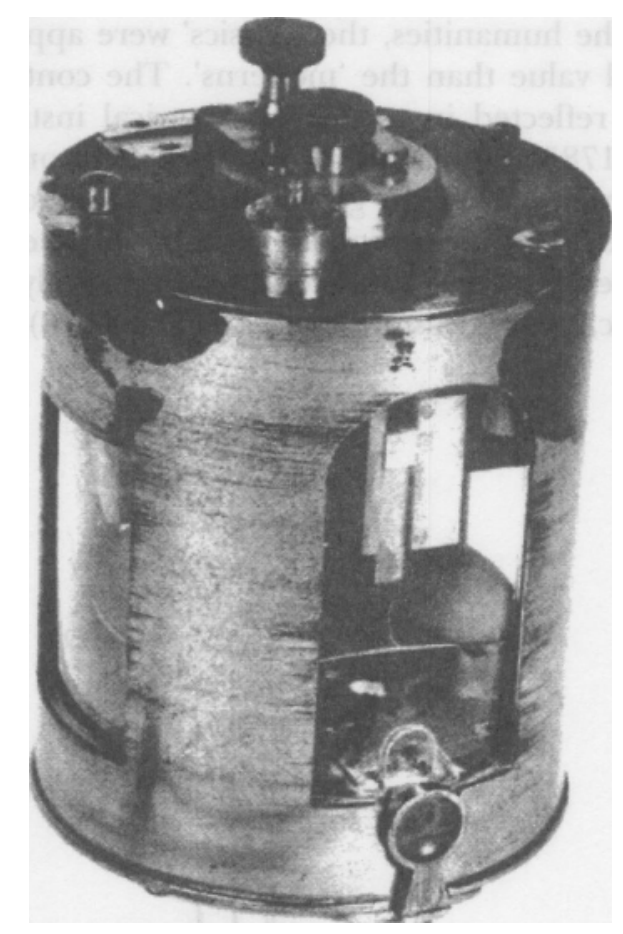

Figure 2(b) Thomson's portable electrometer: a metallic shell, a short torsion wire (1872).

design corresponded to different ideas about what the main characteristics of an instrument were. Sensitivity and demonstrative value counted on the one hand, manipulability and reliability of measurement on the other.

\section{THE INSTRUMENT IN THE PHYSICS LABORATORY: TO BUILD WITH ONE'S OWN HANDS}

Electricity, unlike optics or astronomy, was a science born from the study of artefacts, of instruments and of artificial phenomena created in the laboratory. One needed machines to produce electrical effects. Instruments thus participated intimately in the definition of phenomena and their magnitude, they were themselves objects of study. The extent of scientific output directly concerned with the study of apparatus and instruments bears witness to this. 66 As the traditional view holds, electrical instruments in the 19th century, unlike those of the previous period - the Leyden jar for example - were no longer the sites for theoretical debates or at the centre of scientific controversies. The instrument became 'transparent'. 67 The transparent instrument is one whose object and functioning is no longer controversial, is no longer mysterious. We can distinguish this character of transparency - which can always be challenged - from the 
process of transforming an instrument into a 'black box'.68 It is true that in a second phase (though the two could occur simultaneously) an instrument is indeed black-boxed. Its use is simplified, it is rendered accessible to the non-specialist, and it is more or less standardized. Its mechanism now hidden, preliminary adjustments are done away with, the reading of the result of the measurement is direct and no longer requires recourse to calculations or to numerical tables. This transformation of the instrument into a transparent object, and then into a black box, is a more or less lengthy process which, in the case of electricity, was only achieved for a small category of instruments in the 19th century, that of measuring instruments.

Another useful distinction introduced by W. Hackmann is that between instruments which are active and those which are passive during a scientific investigation. ${ }^{69}$ On the one hand we have electrometers and galvanometers - along with chronometers, balances, telescopes, microscopes - whose role is restricted to providing measurements or observations. On the other we have the electrical machine and, one might add, the Crookes tube which (like the pneumatic machine) created new phenomena or imitated nature. Even here though with the passage of time many instruments passed from the status of active to passive instrument so that this distinction can always be questioned. Anyway it often depends on the context of utilization. Each instrument - battery, galvanometer, electrometer, Ruhmkorff coil, discharge tube, and so on - is alternatively an object of study in itself and a tool to study other objects or phenomena.

These characterizations which change over time also do so according to the space in which the instrument is used. What is a neutral and unproblematic object for one discipline can be a source of controversy for another, for a technical domain, or at the frontier between two disciplines. The chemists, for example, used the battery as a passive instrument in chemical analysis using electrolysis. For physicists and a certain number of chemists, by contrast, the battery - and originally the electric current - remained a topic of theoretical debate and the object of intense controversy for the first three decades of the century. ${ }^{70}$ Similarly, the galvanometer, the physicists' agreed instrument for measuring current, was to be found - as instrument per se - at the heart of a lively debate in physiology between Emil Du Bois Reymond and Carlo Matteucci, who wanted to measure rapidly changing muscular currents.

The transformation into a 'black box' was seen in different ways in different milieux. Sought often for industrial application at the end of the century, it was not always regarded as a step forward by the academics. French physicists were particularly unhappy with the way instruments were being transformed. Be it P. Bertin at the Ecole normale supérieure, A. Cornu at the Ecole polytechnique, or P. Desains, J. Jamin or G. Lippmann at the Sorbonne, all strongly favoured the construction of his apparatus by the experimentalist. ${ }^{71}$ Even if, in practice, they used instruments which were, at least partly, built by an instrument maker, the savant's ability to build it all himself remained an ideal. These physicists evoked the memory of Fresnel who established the theory of the wave nature of light with very precise experiments carried out with optical instruments knocked together with the village carpenter. Certainly British or German physicists - people like 
Helmholtz, Hertz or Kelvin - also built their instruments with their own hands. By contrast their students often seem to have been educated with apparatus built by instrument makers. ${ }^{72}$ French students beginning research had to learn to do without instruments available on the market as much as possible, certainly for financial reasons, but also so as to stimulate their experimental skills and technical competence. Edouard Branly is one of many such examples. When he was preparing his thesis at the Sorbonne, in 1873, he constructed a Thomson electrometer using his own hands, even if this was a very common instrument at that time. ${ }^{73}$ And even if his thesis did little to advance the 'state of theory', it produced a simplified version of Thomson's electrometer which would later be successfully commercialized by Bourbouze (Fig. 2(a)). Foreign observers noticed the determination of French physicists to control entirely their instruments, and their lack of interest in direct measuring instruments designed for industrial use which began to appear in the 1890s. Thus the Electrician invited Alfred Cornu in 1895 to present the French point of view in an exchange with W.E. Ayrton, a London professor of electrical engineering. The latter wanted to introduce direct reading commercial ampère-meters into the practical work of students. Cornu replied that he saw in this a real danger to the education of students and even to the spirit of discovery and invention. 74

We remarked earlier on a movement of 'scientification' among French instrument makers in the course of the 19th century, a process whereby they drew close to the scientific community. We find, symmetrically, a movement of physicists toward instrumentation and the technical world. At the start of the century those working on the mathematization of the theories of electricity, of magnetism, and of electromagnetism (Ampère, Biot, Poisson, Savary, Liouville ... ), valued theoretical achievements above experimental practice, or even despised it openly as did Poisson. Experiments were supposed to correspond precisely with mathematical models. Instruments simply represented the material conditions which defined the experiment. Nothing new was to be expected from them, one even had to be ready to ignore small differences with theory which could emerge from them, differences which could only be due to instrumental defects or to parasitic phenomena similar to friction in mechanics. For an Ampère an apparatus could remain a virtual object, existing only on paper. Detailed drawings accompanied by a precise description sufficed to guarantee its demonstrative function.

From the 1830s onward physicists of the next generation, like Pouillet, Antoine-César Becquerel and then his son Edmond, Despretz, Babinet, Foucault, Fizeau, prized experimentation over theory. They no longer shared the faith of their predecessors in the mathematization of the phenomena they studied. A physicist like Antoine-César Becquerel, who dominated the field of electricity for more than forty years in France, was far less interested in the relationships between physics and mathematics than in those which could exist between physics, chemistry, and life sciences. Most physicists carried out experiments on the relationships between electricity and living organisms.

A new discourse was born, a new vocation was given to physics. Deferential references to Newton's genius, common at the start of the century, were replaced by evocations of the future of industry. As Pouillet put it, "Physics enters the 
workshops to bring the desire for precision and to give full reign to inventive genius". 75 Of course many of these remarks remained mostly more rhetoric. Pouillet himself was not particularly keen to teach courses on machines during his classes at the Conservatorire des arts et métiers, refused to open the physics rooms to the artisan public and condemned the electric telegraph as an "unrealizable chimera". However, at the same time his treatise on physics is filled with descriptions of instruments and apparatus, he published the Conservatoire's port-folio of industrial technical drawings and, at the end of his life, he worked extensively on lightning conductors. Most physics professors wrote reports on technical objects for the Société d'encouragement pour l'industrie nationale, or for the Bureau consultatif des arts et métiers. Unlike Pouillet, A.C. Becquerel unhesitatingly devoted his time to industrial research on electrochemistry, in collaboration with a metallic minerals firm. From mid-century onwards Arago was criticized, in his capacity as permanent secretary of the Académie des sciences, because the prizewinning works selected by the Academy were biassed towards technical aspects and not sufficiently theoretical. ${ }^{76}$ At the end of the century, most physicists were actively involved with instrumentation, and participated in the study of objects for industrial electricity. Many left their name to instruments or to technical equipment: A.-C. Becquerels' differential galvanometer, Foucaults' switch for the Ruhmkorff coil, Bertin commutator, Lippmanns' capillary electro meter, Mascart electrometer, Pierre Curies' electrometer built in collaboration with the instrument maker Bourbouze, Pellats' electrodynamometer, and so on (see Fig. 3). Pierre Curie apart - he was both experimenter and theoretician - these physicists did not, however, have a law or a phenomenon named after them.

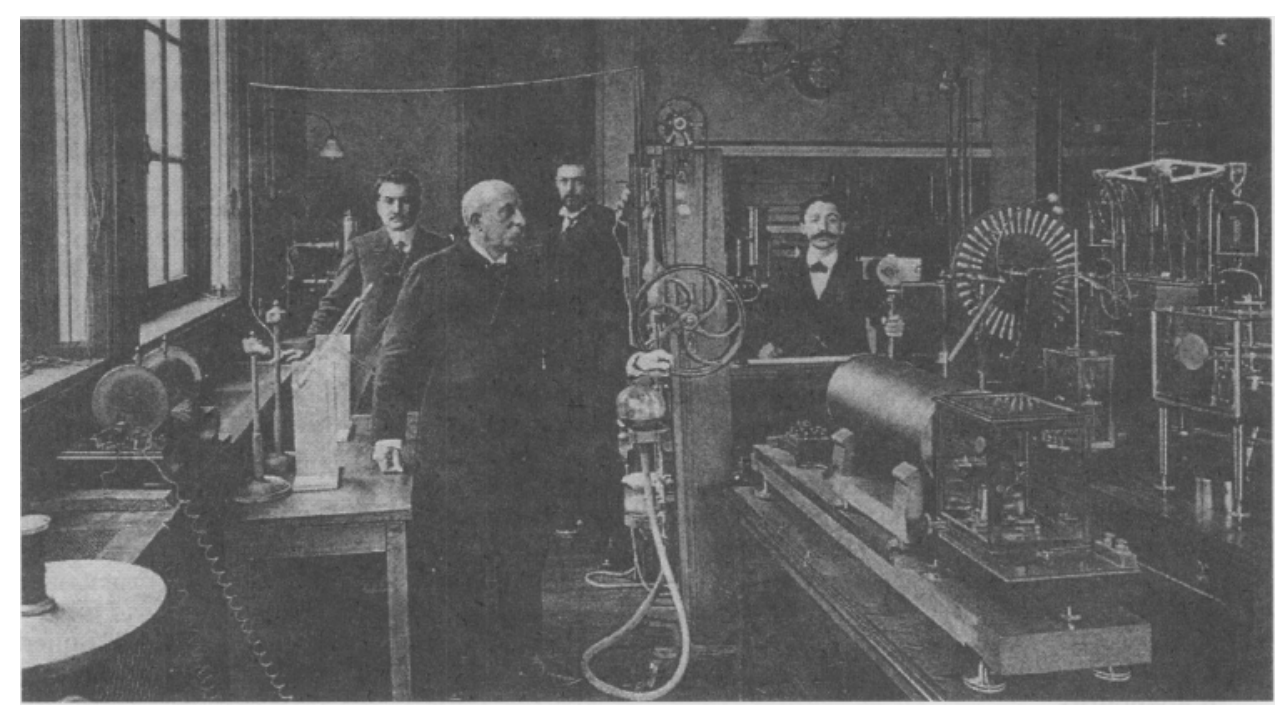

Figure 3 The new physics research laboratory at the Sorbonne, opened in 1894. On the left the Ruhmkorff coil. On the right, in front, Pellat's electrodynamometer, and in the background, the Wimshurst electrostatic machine. 
Besides publications, they received credit for the demonstration of instruments and, possibly, patents. Eleuthère Mascart, professor at the Collège de France, studied the alternator and photography controlled by an electric current, just to mention the applications associated with electricity which interested him. These technical labours did not, however, lead to a formal collaboration with industrial firms. If Aimé Witz, the professor of physics at the Institut catholique in Lille could affirm, in a survey of the progress of physics in the 1880's, that "The physicist had become engineer"(77), it was rather because of his intellectual interest rather than by virtue of his links to the industrial world. While Kelvin participated directly in the establishment of the Kelvin \& White instrument company, French physicists had barely any ties to firms (78). Their involvement remained restricted even when they served as technical consultants.

Translated by John Krige

Notes

1. D.J. de Solla Price, "Philosophical Mechanisms and Mechanical Philosophy: Some Notes towards a Philosophy of Scientific Instruments", Annali dell'Istituto e Museo di Storia della Scienza di Firenze (1980), 5: 75-85.

2. A. van Helden, T.L. Hankins, "Introduction: Instruments in the History of Science", Osiris (1994), 9: 1-6.

3. J.A. Bennett, "Instrument makers and the 'Decline of Science in England': the effects of institutional change on the élite makers of the early nineteenth century", in P.R. de Clercq (ed.), Nineteenth-Century Scientific Instruments and their Makers (AmsterdamLeiden: Rodopi, 1985), p. 19.

4. W.D. Hackmann stresses the small amount of research done, even in this direction, on the 19th century in "Instrumentation in the Theory and Practice of Science: Scientific Instruments as Evidence and as an Aid to Discovery", Annali dell'Istituto e Museo di Storia della Scienza di Firenze (1985), 10: 87-115.

5. W.D. Hackmann, "The nineteenth-century trade in natural philosophy instruments in Britain", in P.R. de Clercq (ed.), Nineteenth-Century Scientific Instruments... (note 3), p. 58; a significant example is supplied by A. Chapman, "Scientific instruments and industrial innovation: the achievement of Jesse Ramsden", in R.G.W. Anderson, J.A. Bennett, W.F. Ryan (eds.), Making Instruments Count. Essays on Historical Scientific Instruments Presented to Gerard L'Estrange Turner (Aldershot: Variorum, 1993), pp. 418-430.

6. R.G.W. Anderson, "Were scientific instruments in the nineteenth century different? Some initial considerations", in P.R. de Clercq (ed.), Nineteenth-Century Scientific 
Instruments ... (note 3), p. 11.

7. For the collective works successively published see: D. Gooding et al. (eds.), The uses of experiment. Studies in the natural sciences (Cambridge: Cambridge Univ. Press, 1989); C. Blondel et al. (eds.), Studies in the History of Scientific Instruments (London: Roger Turner Books Ltd, 1989); G. L'E. Turner (ed.), Gli Strumenti (Torino: Einaudi, 1991); R. Bud, S.E. Cozzens (eds.), Invisible connections: Instruments, institutions and science (Bellingham: SPIE Optical Engineering Press, 1992); R.G.W. Anderson et al. (eds.), Making Instruments Count... (note 5); A. van Helden, T.L. Hankins (eds.), Instruments, Osiris, 9, 1994; M.N. Wise (ed.), The Values of Precision (Princeton: Princeton Univ. Press, 1995); T.L. Hankins, R.J. Silverman (eds.), Instruments and the imagination (Princeton: Princeton Univ. Press, 1995); P. de Clerq, A. Turner (eds.), Origins and evolution of collecting scientific instruments, Journal of the History of Collections, 7, 1995. For the Iiterature specifically devoted to instruments and museums see the annual bibliography edited b G. L'E. Turner since 1983 (circulated by the Scientific Instruments Commission of IUHPS). I

8. Bulletin of the Scientific Instrument Society (1983-). Among recent theses are to be mentioned C. Licoppe (Paris), B. Lelong (Paris), C. Frémontier (Paris), A. Walters (Berkeley), P. Heering (Oldenburg).

9. According to P. Delesalle (Les conditions du travail chez les ouvriers en instrumentation de précision de Paris, 1899, p. 6), in 1849 only around five hundred workers were employed in the Parisian precision industry. During the second half of 19th century, several French makers exported about half of their production (Questionnaires aux exposants de l'Exposition universelle de 1878, 
Archives nationales F12/3362-63). On the role of the scientific instrument industry in technical innovation see for example M. Williams, "Technical innovation: examples from the scientific instrument industry", in J. Liebenau (ed.) The Challenge of New Technology. Innovations in British Business since 1850 (Aldershot: Gower, 1988), pp. $8-29$.

10. J.C. Maxwell, "General considerations concerning scientific apparatus", in South Kensington Museum, Handbook to the Special Loan Collection of Scientific Apparatus (London, 1876), p. 2. On the origins and history of this term see D.J. Warner, "What is a scientific instrument, when did it become one, and why ?", British Journal for the History of Science (1990), 23: 83-93.

11. M. d'Ocagne, "Les instruments de précision en France", Conférence faite au Conservatoire des Arts et Métiers, Revue des questions scientifiques (1904), 55: 353415, on p. 354.

12. On the reproduction in the laboratory of the aurora borealis see W.D. Hackmann, "Instruments and Reality: The case of terrestrial magnetism and the northern light (aurora borealis)" in R. Fellows (ed.), Philosophy and Technology, Suppt to Philosophy (1995), 38: 29-51.

13. An inventory of makers' catalogues to be found in anglo-saxon libraries is R.G.W. Anderson, J. Burnett, B. Gee, Handlist of Scientific Instrument-Makers' Trade Catalogues 1600-1914 (Edinburgh: National Museums of Scotland, 1990).

14. For an overview of 19th century instruments see G. L'E. Turner, Nineteenth-Century Scientific Instruments (London: Sotheby Publications, 1983); P.R. de Clercq (ed.), Nineteenth Scientific Instruments ... (note 3). For catalogues of electrical instruments see for example K. Lyall, Electrical and Magnetic Instruments (Cambridge: Whipple Museum of the History of Science, 1991), or W.D. Hackmann, Catalogue of Pneumatical, Magnetical and Electrical Instruments (Florence: Museo di Storia della Scienza, 1995).

15. D. de Solla Price, "Philosophical Mechanisms ... "(note 1), p. 82.

16. M.N. Wise, "Mediating Machines", Science in Context (1988), 2: 77-113 and "Mediations: Enlighten-ment Balancing Acts, or the Technologies of Rationalism", in P. Horwich (ed.), World Changes. Thomas Kuhn and the Nature of Science (Cambridge Mass.: MIT Press, 1992), pp. 207-256. 
17. G. Turner, "Scientific instruments", in P. Corsi, P. Weindling (eds.), Information

Sources in the History of Science and Medicine (London: Butterworth, 1983), 243-258 on p. 243.

18. On the innovations introduced by Gauss and Weber in the measurement of terrestrial magnetism see M. D\&rries, "La standardisation de la balance de torsion dans les projets européens sur le magnétisme terrestre" in C. Blondel, M. Dbrries (eds.), Restaging Coulomb. Usages, controverses et réplications autour de la balance de torsion (Florence: Olschki, 1994), pp. 121-149.

19. R. Bud and S.E. Cozzens, Invisible Connexions (note 7), p. 3.

20. On French makers see J. Payen, "Les constructeurs d'instruments scientifiques en France au XIXe siècle", Archives internationales d'histoire des sciences (1986), 36: 86-61; P. Brenni, "L'industria degli strumenti scientifici in Francia nel XVIII e XIX secolo", in G. L'E. Turner (ed.), Gli Strumenti (Torino: Einaudi, 1991), pp. 450-463; P. Brenni, "19th Century French Scientific Instrument Makers", Bulletin of the Scientific Instrument Society: "Gambey" (1993), 38: 11-13; "Chevalier" (1993), 39: 11-14; "Lerebours" (1994), 40: 3-6; "Ruhmkorff" (1994), 41: 4-8; "Carpentier" (1994), 43: 12-15; "KSnig" (1995), 44: 13-17; "Froment" (1995), 45: 19-24; "Ducretet" (1995), 46: 12-17; "Richard" (1996), 48: 10-14; "Brunner and Gautier" (1996), 49: 3-8; C. Blondel, "Réponses d'une profession ancienne à de nouveaux besoins: les 'ingénieurs-constructeurs' d'intruments électriques à la fin du XIXe siècle", Bulletin d'histoire de l'électricité, 1988, 11: 103-120.

21. M. Daumas; "Le corps des ingénieurs brevetés en instruments scientifiques (1787)", Archives internationales d'histoire des sciences (1952), 31: 86-96; M. Daumas, Scientific Instruments of the 17th \& 18th Centuries (New York, 1972) (French ed., 1953); J.-D. Augarde, "La fabrication des instruments scientifiques du XVIIIe siècle et la corporation des fondeurs", in C. Blondel et al. (eds.), Studies in the History ... (note 7), pp. 52-72; A.J. Turner, From Pleasure and Profit to Science and Security. Etienne Lenoir and the transformation of precision instrument-making in France, 1760-1830 (Cambridge: Whipple Museum, 1989).

22. On Fortin and Lenoir being almost illiterate see Daumas, Scientific instruments ...(note 21), p. 103; A.J. Turner, From Pleasure ... (note 21), p. 58.

23. Watkins and Hill, A new and enlarged descriptive Catalogue of optical, mathematics, 
physics and chemical instruments and apparatus (London, 1840).

24. cf J.L. Heilbron, "Some uses for catalogues of old scientific instruments", in R.G.W. Anderson et al. (eds.), Making Instruments Count ... (note 5), pp. 1-16.

25. S. Shapin, "The invisible technician", American Scientist (1989), 77: 554-563.

26. M. G. Bigourdan, "Le Bureau des Longitudes: son histoire et ses travaux de l'origine (1795) à ce jour", Annuaire du Bureau des Longitudes (1928), Al-A72.

27. "Froment ne publiait rien, ne communiquait rien aux académies", J. Bertrand, "Marcel Deprez", Revue générale d'électricité (1935), 38, p. 838. An article written by Hachette describes Pixii's 
machine (Annales de Physique et de Chimie, 1832, 50, p. 322); Arago, "Discours funéraires, Gambey", Oeuvres complètes, Notices biographiques (Paris, 1855), t. 3, 601-608 on p. 606.

28. "Les savants doivent respecter jusqu'au scrupule les droits des artistes qui travaillent pour eux", cited by Abbé Moigno, Traité de télégraphie électrique (Paris, 1852), 2e ed., p. 118. Napoléon III's visits to the makers' workshops are regularly reported by Moigno in his journal Cosmos, for Ruhmkoff's see E. Kosack, Heinrich Daniel Ruhmkorff. Ein Lebensbild zu seinem 100 Geburtstage (Leipzig, 1903), p. 32.

29. L'industrie française des instruments de précision, Catalogue publié par le Syndicat des Constructeurs en Instruments d'Optique et de Précision, (Paris, 1901-1902; re-issued Paris: A. Brieux, 1980), Préface A. Cornu, p. VI, X.

30. The Royal Society Catalogue of Scientific Papers (1800-1900) gives for the most important makers concerned with electricity: no publication by Dumotiez, Pixii, Froment, Gambey, Ruhmkorff, 10 by Louis Breguet since 1841 (5 of them in collaboration with a physicist), 12 by Bourbouze since 1862, 18 by A. Gaiffe since 1868, 17 by A. Breguet since 1875, 28 by Ducretet since 1875, 20 by Carpentier since 1879.

31. Ministère du commerce, de l'industrie, des postes et télécommunications, Rapports du jury international. Expostition universelle internationale de 1900. Groupe I, Education et enseignement, Sème Partie, Classe 6, Paris, 1903, p. 309; J.G. Bourbouze, Modes opératoires de physique (assemblés et augmentés par Ch. Hémardinquer, ancien élève du cours Bourbouze), (Paris, 1896).

32. Bulletin des séances de la Société française de physique (1873), 1, p. 7; R. Fox, "Science, the University and the State in Nineteenth-Century France" (1984) reproduced in Science, Industry and Social Order in Post-Revolutionary France (Aldershot: Variorum, 1995), pp. 66-145 on pp. 106-107; M. Atten, Les théories électriques en France, 1870-1900, Thèse de doctorat (Paris: EHESS, 1992), t. 1, pp. 21-28; J.L. Davis, Physics in France circa, 1850-1914. Its national organisation, characteristics and content, Ph.D. (University of Kent, 1990), pp. 120-131.

33. Bulletin des séances de la Société française de Physique (1874), p. 113; one is reminded of the preponderance of experiments on theories by M. Brillouin who is critical about it in "Les débuts de la Société française de physique", Le livre du Cinquantenaire de la Société française de physique (Paris, 1925), 5-18, on p. 16. 
34. Bulletin des séances de la Société française de Physique (1875), p. 135.

35. A. Guérout (assistant manager of the Carpentier company) in La Lumière électrique,

A. Gaiffe in L'électricité, A. Niaudet (assistant manager of the Bréguet company) in L'électricien.

36. La Revue scientifique, 14 February 1880, p. 765.

37. P. Delesalle, Les conditions du travail... (note 9), p. 31.

38. P. Delesalle, Les conditions du travail... (note 9), p. 7; A. Cornu, L'industrie française... (note 29), p. VIII, X,XI; J. Violle, De l'avenir de nos industries physiques après la guerre (Paris, 1915), pp. 58-68.

39. J. Payen, "Les constructeurs d'instruments scientifiques ... " (note 20), p. 86.

40. P. Brenni, "I costruttori stranieri di strumenti scientifici nelle collezioni italiane" in E. Borchi

et al. (eds.), Strumenti diisica e cultura scientifica nell'Ottocento in Italia (Florence, 1993), pp. 103-110.

41. During the last quarter of the century a notable exception was Claude Bernard's laboratory at the Collège de France.

42. On the visits by Arago, Biot, Babinet, Jamin to Soleil's workshop see P. Brenni,"Soleil -Dubosq-Pellin: a Dynasty of Scientific Instrument makers" in G. Dragoni et al. (eds.), Proceedings of the eleventh international Scientific Instrument Symposium (Bologna: Grafis Edizioni, 1991), pp. 107-111 on p. 108; on the collaboration between Marcel Deprez and Jules Carpentier in the latter's workshop see C. Blondel, "Entre l'électrophysiologie et l'électricité industrielle: le galvano-mètre à cadre mobile" in C. Blondel et al. (eds.), Studies in the history ... (note 7), pp. 185-186.

43. Letters from Paul Broca, André Blondel, Marcel Brillouin, Henri Le Chatelier to the maker Pellin (CDHT, Conservatoire national des arts et métiers); letter from d'Arsonval to J. Carpentier in C. Blondel, "Entre l'électrophysiologie..." (note 42), p. 187.

44. D. Manetti, "Scienza, tecnologia e economia: 1'invenzione della dinamo", Annali di stories dell'impresa (1988), 4: 279-367.

45. L. Chauvois, D'Arsonval. Soixante-cinq ans à travers la Science (Paris, 1937), pp. 166, 178-181.

46. J. Payen, "Les constructeurs d'instruments scientifiques..." (note 20), p. 105.

47. "Lettre de M. Froment", Comptes rendus des séances de l'academie des sciences (1859), 48: 461-462. 
48. "Rapport de M. Lamy sur l'industrie du nickelage et ('introduction en France de cette industrie par M. Gaiffe", Bulletin de la Société d'encouragement pour l'industrie nationale (1872), 19, p. 163. On the use of aluminium see A. McConnell, "Aluminium and its Alloys for Scientific Instruments, 1855-1900", Annals of Science (1989), 46: 611-620.

49. A. Butrica, From Inspecteur to ingénieur: Telegraphy and the genesis of electrical engineering in France, 1845-1881, Ph.D. (Iowa State University, 1986). 
50. The complete title of the journal is Repertorium fur physikalische Technik und mathematische und astro nomische Instrumentenkunde. On the Physikalischtechnische Reichsanstalt see D. Caban, An Institute for an Empire. The PhysikalischTechnische Reichanstalt, 1871-1918 (Cambridge: Cambridge Univ. Press, 1989).

51. The expression "commercialisation of leisure", introduced by J.H. Plumb, The commercialisation of leisure in 18th century England (Reading, 1973), is taken up by S. Schaffer for 18th scientific spectacles in "Natural philosophy and public spectacle in the 18th Century", History of Science (1983), 21: 1-43 on p. 6.

52. G. L'E. Turner, "Scientific Toys", British Journal for the History of Science (1987), 20: 377-398.

53. For Haüy, an experiment is "degraded" and to be rejected if it may suggest a charlatan trick

(cf. C. Blondel, "Hàuy et l'électricité: de la démonstration-spectacle à la diffusion d'une science

newtonienne", Revue d'histoire des sciences, 1997).

54. La Nature (1889-2), pp. 29-30.

55. A. Laussedat, Notice biographique sur Gustave Froment (Paris, 1865), p. 20.

56. Dr Fau et Ch. Chevalier, Nouveau manuel complet du Physicien-préparateur ou description d'un cabinet de physique (Paris, 1853), p. 1.

57. R. Fox, "Les conférences mondaines sous le Second Empire", (1989) re-issued in Science, Industry and Social Order in Post-Revolutionary France (Aldershot: Variorum, 1995), p. 51. On the popularization of electricity during the last decades of 19th century, see F. Cardot, "L'électricité, merveille du siècle" and "L'électricité au quotidien" in F. Caron, F. Cardot (eds.), Histoire de l'électricité en France, 1881-1914 (Paris: Fayard, 1991), pp. 212-245, 461-491.

58. R. Fox, "Les conférences mondaines..." (note 57); B. Béguet, "La science mise en scène: les pratiques collectives de la vulgarisation scientifique au XIXe siècle", in B. Béguet (ed.), La science pour tous, 1850-1914 (Paris: Bibliothèque du CNAM, 1990), pp. 129-147; P. Le Boeuf, "La science amusante", in B. Béguet (ed.), id, pp. 96-111; M. Lagrée, "L'abbé Moigno vulgarisateur scientifique (1804-1884)", in Christianisme et science (Paris: Vrin, 1989), pp. 167-182; G. Bodé, "Les associations Polytechnique et Philotechnique entre 1830 et 1869" in B. Belhoste et al. (eds.), Le 
Paris des Polytechniciens. Des ingénieurs dans la ville (Paris: DAVP, 1994), pp. 62 67.

59. H. Tresca, "Compte-rendu de la soirée scientifique du 29 octobre 1864 au Conservatoire des arts et métiers", Annales du Conservatoire des arts et métiers (1864-1865), 5: 205-288; V. Meunier, La science et les savants en 1864 (Paris, 1865), chap. 29; id, La science et les savants en 1865 (Paris, 1866), chap. 30; "Les conférences de la Sorbonne", La Nature (1878- 1), pp. 299.

60. "Les expériences publiques au Conservatoire des arts et métiers", La Nature (1881-2), pp. 14-15; La Nature (1880-2), p. 375; C. Fontanon, D. Pestre, "Les 'leçons du dimanche"' in M. Le Moël, R. Saint-Paul (eds.) 1794-1994. Le Conservatoire national des arts et métiers au coeur de Paris (Paris: DAVP, 1994), pp. 102-107.

61. A. Loiseau, Notice illustrée sur les expériences curieuses et amusantes que l'on peut répéter avec la bobine de Ruhmkorff (Paris: 15th ed., 1906).

62. Some makers, like Bourdon or Radiguet, become specialised in the field of models.

63. M. Brillouin, "Bertin-Mourot", Centenaire de l'Ecole Normale 1795-1895 (Paris, 1895), pp. 401-406

64. The comparison can be made between university treatises at the end of 19th century: J. Jamin \& E. Bouty (Cours de physique de l'Ecole polytechnique, 4th ed., 1885-1906) or H. Pellat (Cours de physique, 1893) and A. Winkelmann (Handbuch der Physik, 4 vols, Breslau, 1891-95) or W. Thomson \& P. Tait (Treatise on natural philosophy, Cambridge, 1879). However this is in no way systematic, Poincaré's treatises being an outstanding exception.

65. H. Bouasse, "Enseignement des sciences physiques dans l'enseignement secondaire", journal de l'enseignement secondaire (1901), cited by N. Hulin, "Les instruments dans l'enseignement scientifique au XIXe siècle", L'instrument, Corps écrit (1990), 5: 3943 on p. 41. On the persistence of the higher status given to an historical, inductive and experimental presentation in French physics textbooks even after the first world war, see D. Pestre, Physique et physiciens en France. 1918-1940, (Paris: Archives contemporaines, 1984), p. 40.

66. The contents of the journals (essentially the Comptes rendus des séances de l'académie des sciences, the Annales de physique et de chimie and from 1872 the Journal de physique) show this close relation between instruments and technical objects.

67. On the introduction and use of the concept of transparency by M. Polanyi, T. Pinch, S. 
Schaffer, J. Bennett, see J.L. Heilbron, "Some uses for catalogues..." (note 24), p. 13.

68. T. Pinch, Confronting Nature (Dordrecht: Reidel, 1986), pp. 212-214.

69. For a discussion on active and passive instruments between J. Bennett and W.

Hackmann see D. Gooding et al. (eds.), The Uses of Experiment... (note 7), pp. 39-41, $105-107$.

70. Among the controversies that have arisen around the electrical battery, the debate between Faraday and Sturgeon on the measurement of the current is studied by I.R. Moms, "The sociology 
of sparks: an episode in the history and meaning of electricity", Social Studies of Sciences (1988), 18: 387-417.

71. E. Picard, La vie et l'oeuvre de G. Lippmann, Institut de France, 14 décembre 1931; L. de Launay,

"Souvenirs intimes", in (Madame Cornu), Alfred Cornu, 1841-1902 (Rennes, 1904), p. 39.

72. On the making by the physicists and their " garçons de laboratoire" of their instruments, see

P. Forman, J. Heilbron, S. Weart, Physics circa 1900, Historical Studies in Physical Sciences (1975), 5:

83-89. On the training of students by William Thomson see G. Gooday, "Precision measurement and the genesis of physics teaching laboratories in Victorian Britain", British Journal for the History of Science (1990), 23: 25-51.

73. C. Blondel, "Edouard Branly. Dalla parte della scienza" in A. Guagnini, G. Pancaldi (eds.), Cento anni di radio. Le radici dell'invenzione, Roma: Seat, 1995, 303354 on p. 311.

74. G. Gooday, "The morals of energy metering: constructing and deconstructing the precision of the victorian electrical engineer's ammeter and voltmeter", in N. Wise (ed.), The values of precision (Princeton: Princeton Univ. Press, 1995), pp. 272-273.

75. C. -S. -M. Pouillet, Eléments de physique expérimentale et de météorologie (3rd ed., 1837), t. I, p. VII.

76. G.Libri, "Lettres à un Américain sur l'état des sciences en France", Revue des deux mondes (1840),

21: 789-818 on p. 796. On the utilitarism of French university professors from the 1870 s see

R. Fox, Science industry and the social order... (note 32) and R. Fox and G. Weisz (eds.), The

Organization of Science and Technology in France, 1808-1914 (Cambridge and Paris, 1980).

77. A. Witz, Les progrès de la physique de 1878 à 1888 (Paris, 1888), p. 4.

78. On the Kelvin \& White company see M.E.W. Williams, The Precision Makers. A 
history of the instruments industry in Britain and France, 1870-1939 (London:

Routledge, 1994), p. 15, 27. 